\title{
Analyzing Soft Cheeses With Vegetable Additives With Neural Network
}

\author{
Tamara C. Tultabayeva ${ }^{1}$, Urishbay Ch. Chomanov ${ }^{2}$, Mukhtar Ch. Tultabayev ${ }^{3}$, Gulmira S. Kenenbay ${ }^{4}$, \\ Gulzhan E. Zhumaliyeva ${ }^{5}$, Aruzhan Y. Shoman ${ }^{6 *}$, Assiya K. Shoman ${ }^{7}$ \\ ${ }^{1}$ Doctor of Technical Sciences, Academician AAS RK, Head of Laboratory of KazRIPFI, LLP, \\ Almaty, Republic of Kazakhstan, tamara_tch@list.ru, \\ ${ }^{2}$ Doctor of Technical Sciences, Professor, Academician of NAS of Kazakhstan, KazRIPFI, LLP, \\ Head of Department, Almaty, Republic of Kazakhstan, chomanov_u@mail.ru, \\ ${ }^{3}$ Doctor of Technical Sciences, Academician of NAS RK, Researcher at the Astana Branch of KazRIPFI, LLP, \\ shomanyli@mail.ru \\ ${ }^{4}$ Candidate of Technical Sciences, Head the Laboratory of KazRIPFI, LLP, gkenenbay@ mail.ru, \\ ${ }^{5}$ Candidate of Technical Sciences, KazRIPFI, LLP, gulzhan_7171@mail.ru, \\ ${ }^{6 *}$ corresponding author -PhD, Leading Researcher, KazRIPFI, LLP Almaty, Republic of \\ Kazakhstan,shoman_aruzhan@mail.ru, \\ ${ }^{7}$ Senior Researcher, KazRIPFI, LLP, Almaty, Republic of Kazakhstan, a.tultabayeva@mail.ru
}

\begin{abstract}
A wide range of dairy-based products with additives of plant origin is due to the variety of forms of raw materials and methods of processing it. New soft cheeses with vegetable additives have been developed.

Physical and chemical parameters of plant raw materials were studied, and it was found that the wheat germ contains (\%) 28.42 protein, 6.7 - fat, carbohydrates -19.98 . The formula of vegetable additives for the production of soft cheeses has been developed, the ratio of vegetable raw materials and wheat germ is 70:30, while the mass fraction of protein in the additive is $10.6 \%$.

Mathematically, neural networks can be considered as a class of statistical modeling methods, which, in turn, can be divided into three classes: probability density estimation, classification and regression. The problem of estimating the probability density by the method of mixing Gaussian distributions is solved with the help of inverse distribution networks and the generalized d-rule.
\end{abstract}

Key words: Soft cheese, vegetable Supplement, amino acids, vitamins, neural network.

\section{INTRODUCTION}

The main consumers of agricultural products are enterprises of the processing industry, which produce important food products for the population. The state policy as the main priorities provides for a significant expansion of domestic production of food products, increasing the range and ensuring their safety. In this regard, the is-sues of further development of the sphere of production and processing of livestock products are strategically important for the agro-industrial complex of the Republic of Kazakhstan [1].

The modern theory of nutrition pays much attention to the design of the composition of food products. A special role is assigned to protein as the main component that determines the nutritional and biological value of the food system [1]. One of the ways to eliminate acute protein deficiency in the diet of people is to create new types of food, including dairy products, using plant proteins [2]. The combination of animal and vegetable proteins in the product allows us to use the principle of complementarity [3].

Cheese is a unique food product, the properties of which are very diverse. There are a huge number of its species in the world. Ordering the assortment of cheeses, improving their specific structure is currently relevant and can ensure the production of cheeses with a high yield, increase the volume of gross output, and obtain high production profitability [4].

To train the neural network, an array of input vectors xi (x1 is the mass fraction of cheese in the recipe mixture; $x 2$ is the ratio $B$ / SZR) was formed, which correspond to the values of the objective function of the score of the consistency of the finished product (Table 1). Creating and learning a neural network is started by a special program created in the MatLab environment [6]. To solve the simulation problem, a three-layer fully interconnected network was formed, including two neurons in the input layer (by the number of components of the input vector), four neurons in the intermediate layer with transfer functions tag-sig and one neuron in the output layer (by the number of components). source vector) with purelin transfer function[6].

The positions of neurons in each layer are determined by the topological function randtop, which forms a random location of neurons in the layer. The linkdist distance function is used to calculate the distances between neurons in the $\mathrm{i}$-th 
layer. The Levenberg-Marquardt (trainlm) algorithm was chosen as the teaching algorithm. The specified network is formed using the following procedure, written in the program Neiron.m: net $=$ newcf $(\operatorname{minmax}(\mathrm{P}),[6]$, \{ 'tansig' 'tansig' 'purelin'\}, 'trainlm'); where the first argument - the matrix of minimum and maximum values of the components of the input vector - is calculated using the procedure minmax. The result of the newff procedure is a neural network net of a given configuration.

Neural network training is to determine the weights and displacements of all synapses in all layers of the NM. The learning parameters were the number of learning cycles (1000) and the target learning error (0.01). In this case, the rms error was chosen as a function of performance evaluation. The learning process is illustrated by a graph of the dependence of performance assessment on the number of the training cycle [5].

\section{MATERIALS AND METHODS}

To obtain a fermented vegetable additive from vegetable crops, carrots and pumpkins in the form of pulp were chosen. Carrot pulp was obtained as follows: peeled and washed table carrots are peeled, cut on tops with a diameter of $5 \mathrm{~mm}$, then wiped on a double cleaning machine through sieves with a hole with a diameter of $0.8-0.5 \mathrm{~mm}$ and separated carrot juice [7-9].

To process the output data, we use the program code [6], which allows to obtain arrays of values of the output variable for some values of the input variables, which change in the same range as in the experimental study. This three-dimensional model is difficult to understand. In this regard, taking into account the need to obtain a product of functional direction, ie with a high content of biologically active substances, the cross section of the surface (Fig. 6) was a plane parallel to the axis "V / SZR" at the maximum value of cheese in the recipe mixture $-30 \%$. The obtained graphical dependence is shown in Figure 1.

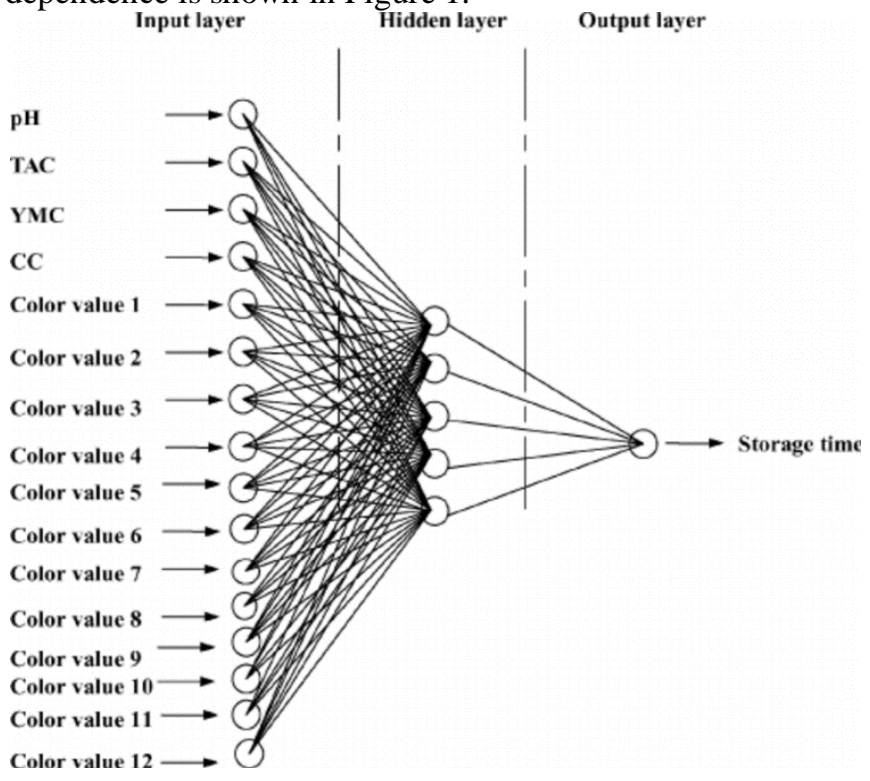

In the obtained vegetable raw materials, the protein, fat and carbohydrate contents were determined (table 1).

Table 1:- Chemical composition of vegetable raw materials

\begin{tabular}{|l|c|c|}
\hline The name of components & Carrot cake & Pumpkin pulp \\
\hline Protein, \% & $0.84 \pm 0.01$ & $0.73 \pm 0.02$ \\
\hline Fat, \% & $1.99 \pm 0.02$ & $1.23 \pm 0.04$ \\
\hline Carbohydrates, \% & $39.75 \pm 0.04$ & $40.08 \pm 0.03$ \\
\hline Moisture, \% & $36.3 \pm 0.03$ & $37.7 \pm 0.02$ \\
\hline Ash, \% & $0.62 \pm 0.01$ & $0.42 \pm 0.01$ \\
\hline
\end{tabular}

Since, in the dairy industry, when using food fibers contained in vegetable raw materials, they are pre-subjected to heat treatment to soften the fiber structure and give them an easily digestible form.

We applied biotechnological methods of processing vegetable raw materials to soften the fiber structure and used the enzyme preparation Pectinase to maximize the preservation of all useful nutrients [5].

The studies were performed at $\mathrm{pH} 6$ with a hydrolysis temperature of $48-50^{\circ} \mathrm{C}$ within 4 hours. The dry matter content of carrot and pumpkin pulp was initially $63.7 \%$ and $62.3 \%$, respectively [11].

When applying an enzyme preparation in the amount of $0.1 \%$ of the mass of vegetable raw materials, the fermentation process was slow, the change in the dissolution of dry substances was slow for 6-8 hours.

When increasing the dose of the enzyme preparation to $0.2 \%$, hydrolysis at $\mathrm{pH} 6$ and temperature $48-50^{\circ} \mathrm{C}$ was more active for 4 hours and an increase in the destruction of dry substances was observed up to $35-37 \%$.

Then, to prepare a plant Supplement, we studied the chemical composition of the wheat germ. The embryo is almost $80 \%$ protein, sugar and fat (table 2).

Table 2 : Chemical composition of wheat germ, $\%$

\begin{tabular}{|c|c|c|c|c|c|c|}
\hline $\begin{array}{c}\text { Product } \\
\text { descriptio } \\
\mathrm{n}\end{array}$ & $\begin{array}{c}\text { Moistu } \\
\text { re }\end{array}$ & $\begin{array}{c}\text { Protei } \\
\mathrm{n}\end{array}$ & Fat & $\begin{array}{c}\text { Carbo } \\
\text { hydrat } \\
\text { es }\end{array}$ & Fiber & Ash \\
\hline wheat & $9.60 \pm 0$ & 35.66 & 11.71 & 17.40 & $2.42 \pm$ & $3.8 \pm$ \\
Germ & .04 & \pm 0.03 & \pm 0.04 & \pm 0.02 & 0.03 & 0.02 \\
\hline
\end{tabular}

Due to the fact that the developed technology for the production of combined soft cheeses involves the use of whole milk, it is necessary to make up for the lack of protein by adding proteins of plant origin in the form of vegetable additives [10].

To obtain a plant Supplement, prepared plant products (fermented carrot and pumpkin pulp, as well as wheat germ) were mixed in a ratio of 70:30, separately carrots+wheat germ and pumpkin+wheat germ.

The result is a plant Supplement containing plant protein, a complex of vitamins, minerals and polyunsaturated fatty acids.

The chemical composition and nutritional value of herbal supplements is presented in table 3 .

Figure 1: Neural network model for analyzing cheese 
Tamara C. Tultabayeva et al., International Journal of Advanced Trends in Computer Science and Engineering, 9(4), July - August 2020,5476 - 5480

Table 3: Chemical composition of additives, g / 100g

\begin{tabular}{|c|c|c|}
\hline Indicator & $\begin{array}{c}\text { carrot-wheat } \\
\text { additive }\end{array}$ & $\begin{array}{c}\text { pumpkin-wheat } \\
\text { additive }\end{array}$ \\
\hline Protein & $10.64 \pm 0.06$ & $10.61 \pm 0.04$ \\
\hline Fat & $3,16 \pm 0.07$ & $2.90 \pm 0.05$ \\
\hline Carbohydrates & $16,7216.72 \pm 0.05$ & $15.98 \pm 0.03$ \\
\hline Moisture & $68.70 \pm 0.03$ & $69.80 \pm 0.05$ \\
\hline Ash & $0.78 \pm 0.01$ & $0.7 \pm 0.06$ \\
\hline $\begin{array}{c}\text { Energy value, } \\
\text { kcal }\end{array}$ & $138 \pm 0.04$ & $132 \pm 0.04$ \\
\hline
\end{tabular}

The main criteria for evaluating the quality of food products are indicators of their nutritional and energy value.

The determination of nutritional value (the complex of product properties that provide a person's physiological needs for energy and basic nutrients - proteins, fats, carbohydrates, vitamins, macro - and microelements) and energy value (the amount of energy ( $\mathrm{kcal}, \mathrm{kJ}$ ) released in the human body from food substances to ensure its physiological functions) are mandatory in the development of new types of products [12-14].

The nutritional and energy value of the developed new combined soft cheeses was determined (table 4).

Table 4 : Nutritional and energy value of combined soft cheeses with vegetable additives ( $\mathrm{g} / 100 \mathrm{~g}$ of the product)

\begin{tabular}{|l|c|c|c|}
\hline \multirow{2}{*}{$\begin{array}{l}\text { Name of } \\
\text { indicators }\end{array}$} & \multicolumn{3}{|c|}{ Soft cheeses with vegetable additives } \\
\cline { 2 - 4 } & control & $\begin{array}{l}\text { with } \\
\text { carrot-wheat } \\
\text { additive }\end{array}$ & $\begin{array}{l}\text { with } \\
\text { pumpkin-wh } \\
\text { eat additive }\end{array}$ \\
\hline Protein & $19.50 \pm 0.05$ & $24.08 \pm 0.07$ & $23.38 \pm 0.04$ \\
\hline Fat & $23.70 \pm 0.06$ & $23.33 \pm 0.06$ & $23.20 \pm 0.07$ \\
\hline $\begin{array}{l}\text { Carbohydrate } \\
\text { s }\end{array}$ & $2.50 \pm 0.05$ & $3.94 \pm 0.05$ & $3.87 \pm 0.05$ \\
\hline Moisture & $50.20 \pm 0.08$ & $45.88 \pm 0.03$ & $46.69 \pm 0.06$ \\
\hline Ash & $3.10 \pm 0.04$ & $2.87 \pm 0.05$ & $2.86 \pm 00.4$ \\
\hline $\begin{array}{l}\text { Energy } \\
\text { value, kcal / } \\
100 g\end{array}$ & $301 \pm 0.05$ & $321 \pm 0.04$ & $318 \pm 0.06$ \\
\hline
\end{tabular}

The combination of whole cow's milk and vegetable additives increases not only the nutritional value, but also the biological value of new products with complex raw materials [15].

The biological value of a product is determined by an indicator of the quality of food protein, reflecting the degree of compliance of the amino acid composition with the needs of the body in amino acids for protein synthesis and is presented in table 5 .

Table 5:Biological value of soft cheese proteins $(\mathrm{mg} / 100 \mathrm{~g}$ protein)

\begin{tabular}{|c|c|c|c|}
\hline \multirow{2}{*}{$\begin{array}{c}\text { Name of } \\
\text { indicators }\end{array}$} & \multicolumn{3}{|c|}{ Soft cheese } \\
\cline { 2 - 4 } & control & $\begin{array}{l}\text { with } \\
\text { carrot-wheat } \\
\text { additive }\end{array}$ & $\begin{array}{l}\text { with } \\
\text { pumpkin-wheat } \\
\text { additive }\end{array}$ \\
\hline $\begin{array}{l}\text { Total amount } \\
\text { of amino acids }\end{array}$ & $\begin{array}{c}19109 \pm 0 . \\
7\end{array}$ & $23598 \pm 0.6$ & $22912 \pm 0.5$ \\
\hline Irreplaceable, & $6944 \pm 0.4$ & $10123 \pm 0.3$ & $9659 \pm 0.8$ \\
\hline
\end{tabular}

\begin{tabular}{|l|c|c|c|}
\hline including & & & \\
\hline Valin & $993 \pm 0.5$ & $1788 \pm 0.3$ & $1353 \pm 0.5$ \\
\hline Isoleucine & $809 \pm 0.4$ & $1299 \pm 0.2$ & $1132 \pm 0.3$ \\
\hline Leucine & $1398 \pm 0.7$ & $2250 \pm 0.6$ & $1991 \pm 0.4$ \\
\hline Lizin & $1251 \pm 0.5$ & $1760 \pm 0.7$ & $1661 \pm 0.6$ \\
\hline Methionine & $487 \pm 0.2$ & $602 \pm 0.3$ & $652 \pm 0.5$ \\
\hline Threonine & $736 \pm 0.7$ & $1080 \pm 0.4$ & $919 \pm 0.5$ \\
\hline Tryptophan & $304 \pm 0.6$ & $317 \pm 0.5$ & $845 \pm 0.8$ \\
\hline Phenylalanine & $966 \pm 0.3$ & $1027 \pm 0.4$ & $1107 \pm 0.5$ \\
\hline $\begin{array}{l}\text { Interchangeab } \\
\text { le, including }\end{array}$ & $12165 \pm 0$. & $13475 \pm 0.7$ & $13253 \pm 0.6$ \\
\hline Alanine & 4 & & \\
\hline Arginine & $727 \pm 0.2$ & $823 \pm 0.6$ & $918 \pm 0.5$ \\
\hline Aspartic acid & $1646 \pm 0.3$ & $1880 \pm 0.3$ & $1354 \pm 0.2$ \\
\hline Histidine & $1117 \pm 0.8$ & $793 \pm 0.2$ & $1139 \pm 0.3$ \\
\hline Glycine & $322 \pm 0.7$ & $348 \pm 0.1$ & $333 \pm 0.5$ \\
\hline Glutamic acid & $3735 \pm 0.4$ & $4486 \pm 0.7$ & $4236 \pm 0.7$ \\
\hline Proline & $1739 \pm 0.5$ & $2046 \pm 0.3$ & $1992 \pm 0.6$ \\
\hline Serine & $1067 \pm 0.6$ & $1163 \pm 0.5$ & $1316 \pm 0.3$ \\
\hline Tyrosine & $1108 \pm 0.7$ & $793 \pm 0.3$ & $1158 \pm 0.4$ \\
\hline Cystine & $138 \pm 0.1$ & $227 \pm 0.4$ & $157 \pm 0.5$ \\
\hline
\end{tabular}

According to the qualitative composition of amino acids in all soft cheeses, no differences were found. The introduction of a vegetable Supplement has increased the quantitative content of certain amino acids in new soft cheeses [15].

Table 6: Fatty acid composition of soft cheeses $(\mathrm{mg} / 100 \mathrm{~g}$ of fat)

\begin{tabular}{|c|c|c|c|}
\hline \multirow{2}{*}{$\begin{array}{c}\text { Name } \\
\text { of acids }\end{array}$} & \multicolumn{3}{|c|}{ Soft cheese } \\
\cline { 2 - 4 } & control & $\begin{array}{c}\text { with carrot-wheat } \\
\text { additive }\end{array}$ & $\begin{array}{c}\text { with } \\
\text { pumpkin-whe } \\
\text { at additive }\end{array}$ \\
\hline $\begin{array}{c}\text { Saturated, } \\
\text { incl }\end{array}$ & $12658 \pm 0.3$ & $15616 \pm 0.4$ & $13112 \pm 0.6$ \\
\hline Oil & - & $772 \pm 0.2$ & $147 \pm 0.4$ \\
\hline Nylon & $185 \pm 0.5$ & $594 \pm 0.3$ & $154 \pm 0.6$ \\
\hline Caprylic & $288 \pm 0.8$ & $653 \pm 0.5$ & $251 \pm 0.6$ \\
\hline Caprine & $843 \pm 0.5$ & $1781 \pm 0.7$ & $706 \pm 0.6$ \\
\hline Lauric & $875 \pm 0.3$ & $1247 \pm 0.6$ & $788 \pm 0.5$ \\
\hline Myristic & $1617 \pm 0.6$ & $2256 \pm 0.7$ & $1968 \pm 0.3$ \\
\hline Palmitic & $5047 \pm 0.7$ & $5997 \pm 0.5$ & $5389 \pm 0.6$ \\
\hline Stearic & $3811 \pm 0.4$ & $2315 \pm 0.7$ & $3706 \pm 0.5$ \\
\hline $\begin{array}{c}\text { Monounsatu } \\
\text { rated, incl }\end{array}$ & $8137 \pm 0.6$ & $6294 \pm 0.8$ & $9090 \pm 0.7$ \\
\hline Myristoleic & $525 \pm 0.3$ & $178 \pm 0.5$ & $672 \pm 0.6$ \\
\hline Palmitoleic & $473 \pm 0.1$ & $588 \pm 0.4$ & $1072 \pm 0.8$ \\
\hline Oleic & $7137 \pm 0.2$ & $5527 \pm 0.1$ & $7345 \pm 0.3$ \\
\hline $\begin{array}{c}\text { Polyunsatur } \\
\text { ated, incl }\end{array}$ & $762 \pm 0.4$ & $1254 \pm 0.2$ & $976 \pm 0.3$ \\
\hline $\begin{array}{c}\text { Linoleic } \\
\text { Acid }\end{array}$ & $762 \pm 0.3$ & $779 \pm 0.5$ & $824 \pm 0.4$ \\
\hline $\begin{array}{c}\text { Linolenic } \\
\text { Acid }\end{array}$ & - & $475 \pm 0.3$ & $152 \pm 0.2$ \\
\hline $\begin{array}{c}\text { Total } \\
\text { amount of } \\
\text { acids }\end{array}$ & $21557 \pm 0.8$ & $23164 \pm 0.5$ & $23178 \pm 0.7$ \\
\hline
\end{tabular}

The vitamin value of milk and dairy products varies significantly depending on the season and conditions of the year, in particular, because of the lack of green feed in winter. Vitamin losses are significant during separation, 
normalization, pasteurization, sterilization, drying and recovery of milk [13].

For this purpose, the enrichment of soft cheeses with vegetable additives gave positive results. Quantitative content of vitamins and minerals in new dairy products is presented in tables 7 and 8 .

Table 7: Vitamin Content in soft cheeses, (in $100 \mathrm{~g})$

\begin{tabular}{|l|c|c|c|}
\hline \multirow{2}{*}{ Vitamins } & \multicolumn{3}{|c|}{ Soft cheeses } \\
\cline { 2 - 4 } & control & $\begin{array}{c}\text { with } \\
\text { carrot-wheat } \\
\text { additive }\end{array}$ & $\begin{array}{c}\text { with } \\
\text { pumpkin-wheat } \\
\text { additive }\end{array}$ \\
\hline $\mathrm{A}, \mathrm{mcg}$ & $205 \pm 0.3$ & $250 \pm 0.2$ & $238 \pm 0.4$ \\
\hline $\begin{array}{l}\beta \text {-carotene, } \\
\mathrm{mcg}\end{array}$ & $54 \pm 0.06$ & $170 \pm 0.6$ & $1242 \pm 0.5$ \\
\hline $\mathrm{In}_{1}, \mathrm{mg}$ & $0.030 \pm 0.005$ & $0.040 \pm 0.005$ & $0.038 \pm 0.001$ \\
\hline $\mathrm{In}_{2}, \mathrm{mg}$ & $0.340 \pm 0.004$ & $0.38 \pm 0.004$ & $0.37 \pm 0.006$ \\
\hline $\mathrm{PP}, \mathrm{mg}$ & $0.40 \pm 0.02$ & $0.50 \pm 0.01$ & $0.54 \pm 0.003$ \\
\hline $\mathrm{S}, \mathrm{mg}$ & $0.50 \pm 0.04$ & $4.10 \pm 0.03$ & $2.72 \pm 0.007$ \\
\hline $\mathrm{E}, \mathrm{mg}$ & $0.32 \pm 0.01$ & $1.20 \pm 0.04$ & $0.57 \pm 0.002$ \\
\hline
\end{tabular}

Table 8: Mineral content of soft cheeses, $\mathrm{mg} / \mathrm{100g}$

\begin{tabular}{|l|c|c|c|}
\hline \multirow{2}{*}{$\begin{array}{c}\text { Name } \\
\text { of } \\
\text { indicators }\end{array}$} & \multicolumn{3}{|c|}{ Soft cheeses } \\
\cline { 2 - 4 } & control & $\begin{array}{c}\text { with } \\
\text { carrot-wheat } \\
\text { laced }\end{array}$ & $\begin{array}{c}\text { with pumpkin-wheat } \\
\text { additive }\end{array}$ \\
\hline $\mathrm{Na}$ & $476 \pm 0.3$ & $800 \pm 0.5$ & $559 \pm 0.8$ \\
\hline $\mathrm{K}$ & $73 \pm 0.07$ & $155 \pm 0.2$ & $111 \pm 0.3$ \\
\hline $\mathrm{Ca}$ & $410 \pm 0.3$ & $510 \pm 0.3$ & $418 \pm 0.7$ \\
\hline $\mathrm{Mg}$ & $332 \pm 0.1$ & $390 \pm 0.6$ & $367 \pm 0.5$ \\
\hline $\mathrm{Fe}$ & $0.44 \pm 0.01$ & $0.51 \pm 0.02$ & $0.55 \pm 0.004$ \\
\hline $\mathrm{P}$ & $17 \pm 0.08$ & $25 \pm 0.1$ & $24 \pm 0.2$ \\
\hline
\end{tabular}

Thus, from tables 7 and 8 , it can be seen that the quantitative content of all vitamins and trace elements increased by 1.5-2 times. New soft cheeses with vegetable additives are enriched with vitamins and trace elements and are biologically complete products, for example, the content of beta-carotene in soft cheeses with carrot and wheat additives has increased by 23 times.

\section{CONCLUSION}

The creation of a neural network model is based on the use of artificial neural networks, which is one of the directions of development of the theory of artificial intelligence. The neural network model consists of several layers of artificial neurons that mimic the work of their biological counterparts (nerve cells). The functioning of a biological neuron is carried out as follows: input signals are received from synapses through thin densely branching processes of the neuron-dendrites, into the cell body - soma, inside which the nucleus is located. Synapses differ from each other in size and the ability to concentrate special chemical substances near their shell. For this reason, impulses of the same magnitude arriving at the inputs of the nerve cell through different synapses can excite it to different degrees. A measure of cell excitation is considered to be the level of polarization of its membrane, which depends on the total number of chemical substances isolated at all synapses. If the excitation of the cell is not great, then no changes are registered at its output. If the sum of excitations exceeds the threshold of cell activation, the value of the output signal begins to increase in an avalanche, taking the form of a nerve impulse. This impulse is diverted from the cell by the axon through its numerous nerve endings and gets to the synapse, through which the input signal goes to other neurons connected to this cell.

Data is collected from measuring instruments installed at most stages of the cheese production process. Data is also received from the Central and shop laboratories, where most of the quality parameters of raw materials, semi-finished products and finished products are measured. The collected data is input to an artificial neural network, which, based on the algorithm embedded in it, evaluates the resulting taste index by several criteria on a ten-point scale.

The principle of operation of a neural network is as follows: a set of input parameters is passed through the neural network, for which the output parameters are known. The weight coefficients of the connections of neurons are calculated - the network is trained. Then, if you enter parameters for which the output is not known, the neural network will build a forecast of their values based on weight coefficients. In order for an artificial neural network to work correctly, it must be trained. For training, a training sample consisting of at least one hundred experiments must be submitted to the input of the neural network. The training sample is prepared as follows: all data is collected, which will then be sent to the input of the neural network. And then the expert Commission, consisting of professional tasters, in the conditions necessary for the tasting, evaluates the taste indicators of finished products made with the parameters measured during the experiment, according to a number of criteria. Neural network training is reduced to selecting optimal synaptic weight coefficients. The most popular learning algorithm for MLP-type networks is the back propagation algorithm. Thus, it is possible to evaluate the quality of the finished product, which was previously somewhat difficult based on the subjectivity of the assessment. It is necessary to conduct a number of tests that will allow you to give the most complete assessment of the quality of the product and train the neural network based on the results to evaluate the quality of all subsequent batches of the finished product.

\section{REFERENCES}

1. Ostroumov L. A., Tsaregorodtseva S. R., Prosekov S. Functional properties of quality improvers of combined dairy products // Food technology. 2001, no. 2-3, Pp. 38-39.

2. Ostroumova T. A., Zakharova L. M., Mazeeva I. A. the Possibility of using grain crops in the production of dairy protein products // Storage and processing of agricultural raw materials. 2002, no. 4, Pp. 41-43.

3. Tultabayeva T. Ch., AmirovaZh. T., Begasylova A. B.Development of technology for the use of enzymatic preparations for the production of combined cheeses// 
Bulletin of agricultural science of Kazakhstan. 2009, no. 6, Pp. 45-50.

4. Tultabayeva T. Ch., AmirovaZh. T., Begasylova A. B., Nurpeisova Z. T. non-Waste technology of milk processing. Sat.Dokl.mezhd.nauchno-prakt. konf. "Innovative approaches in the production, processing and storage of agricultural products". Astana, 2009, p. 244

5. Tultabayeva T.Ch.Chomanov U., R. TarakbayevaEnzymes in food industry/ agro industrial complex as the factor of development of national economy of Kazakhstan: mater. International. scientific and practical conference, Semey, 2004, Pp. 427-430.

6. Aharonovich, A. R., Sergeevich, S. M., \&Vyacheslavovna, D. S. (2019). Institutional framework for entrepreneurship of regional innovation systems of the union state. Academy of Entrepreneurship Journal, 25(Special Issue 1).

7. Glebova, I. S., Kotenkova, S. N., \& Abramov, R. A. (2016). The analyses of socio-economic development tendencies of the capital cities in the modern Russia. In Social Sciences and Interdisciplinary Behavior Proceedings of the 4th International Congress on Interdisciplinary Behavior and Social Science, ICIBSOS 2015 (pp. 189-194).

8. Ivanovich, G. V, Aharonovich, A. R., \&Sergeevich, S. M. (2019). Implementation of international experience in support of youth innovative entrepreneurship in the Union state. Academy of Entrepreneurship Journal, 25(Special Issue 1).

9. Semenyutina, A., Svintsov, I., Huzhahmetova, A., \&Semenyutina, V. (2018). Regulation of increase of biodiversity of woody plants in protective forest plantings of the Volga region. World Ecology Journal, 8(2), 46-59.

https://doi.org/https://doi.org/10.25726/NM.2018.2.2.005

10. Tereshkin, A. (2018). Specificity of optimization of recreational potential Forest park (on the example of the green zone of Saratov). World Ecology Journal, 8(2), 60-70.

https://doi.org/https://doi.org/10.25726/NM.2018.2.2.006

11. Belitskaya, M. (2018). Ecologically adaptive receptions control the number of pests in the ecosystems of transformed at the forest reclamation. World Ecology Journal, 8(2), 1-10.

https://doi.org/https://doi.org/10.25726/NM.2018.2.2.001

12. Dolgikh, A. (2018). Monitoring of introduction resources of the Kulunda arboretum and allocation of valuable gene pool for protective afforestation. World Ecology Journal, 8(1), 29-42 https://doi.org/https://doi.org/10.25726/NM.2018.1.1.003

13. Akour, M., Qasem, O. A., Alsghaier, H., \& Al-Radaideh, K. (2019). The effectiveness of using deep learning algorithms in predicting daily activities. International Journal of Advanced Trends in Computer Science and Engineering, 8(5), 2231-2235.

https://doi.org/10.30534/ijatcse/2019/57852019

14. Akram, U., Ghazali, R., Ismail, L. H., Zulqarnain, M., Husaini, N. A., \& Mushtaq, M. F. (2019). An improved Pi-Sigma neural network with error feedback for physical time series prediction. International Journal of
Advanced Trends in Computer Science and Engineering, 8(1.3 S1), 276-284. https://doi.org/10.30534/ijatcse/2019/5381.32019

15. Al Ashhab, Z. R., Anbar, M., Singh, M. M., Alieyan, K., \&Ghazaleh, W. I. A. (2019). Detection of http flooding ddos attack using hadoop with mapreduce: a survey. International Journal of Advanced Trends in Computer Science and Engineering, 8(1), 71-77. https://doi.org/10.30534/ijatcse/2019/12812019 